\title{
African Union and Conflict Resolution in Africa
}

\section{Professor Chika Njideka Oguonu}

\author{
Department of Public Administration and Local Government, University of Nigeria Nsukka \\ Email: chika.oguonu@unn.edu.ng

\section{Dr Christian Chukwuebuka Ezeibe}

\author{
Department of Political Science University of Nigeria Nsukka
}

Email: Christian.ezeibe@unn.edu.ng

\section{Doi:10.5901/mjss.2014.v5n27p325}

\begin{abstract}
This paper examines the roles, limitations and prospects of $A U$ in conflict resolution in Africa. It was conducted using documentary analysis as well as discourse analysis approaches. The paper observed that the mono-cultural political economy of Africa is the immediate cause of conflicts while the remote cause of conflicts in Africa is the arbitrariness in creation of the boundaries. The article examined the Peace Operation in Burundi; role of AU mediation team and the Abuja Inter-Sudanese Peace Talks; African Union Mission in Somalia (AMISOM); AU's role in recent crises in Libya and Côte d'Ivoire. The paper concludes that $A U$ has played very important role in conflict resolution in the region. At least $A U$ raises the alarm for international community to intervene. However, AU's missions have the limitations of financial barriers as well as dearth of technical capacity. The paper recommends that $A U$ should appropriate over $70 \%$ of her annual budget to a special fund for responding to conflict emergencies so that it will react swiftly to conflict emergencies.
\end{abstract}

Keywords: African Union, conflict resolution, peace, intervention, mediation

\section{Introduction}

Conflict is an inevitable part of life and it has recurrent decimal in every political system. As a social problem, it is as old as man and cuts across continents, regions and nations. Conflict arises in societies as a result of rival opinions, divergent wants, competing needs and opposing interests (Heywood, 2007). Conflict can be classified into intra-personal, interpersonal, intra-group and inter-group conflicts. In this paper, we are concerned with intra and inter-group conflicts in Africa.

Ethnic/religions conflicts, border conflicts, civil strife, civil wars and genocides are rampant in Africa. Specific instances of conflicts in Africa include ethnic/religious conflicts which developed into civil wars in Zaire, Sudan, Burundi, Rwanda, Liberia, Uganda and Lesotho to mention but a few; turmoil in Angola; state /rebels conflicts in Serra Leone, Cote D' Ivoire and Guinea Bissau; border conflict (Ethiopia and Eritrea, Nigeria and Cameroon) and genocide in Somali. International Colloquium Report (2012) also observed that since the collapse of the Soviet Bloc that marked the end of the Cold War by 1989/1990, civil conflicts increased in Africa. It took the form of genocide in Rwanda in 1994 resulting in about 800,000 deaths. In fact, fourteen of the sixteen wars fought in Africa from 1990 to 1997 were intrastate wars, and in 1992, the African continent hosted 46.7 percent of all civil wars in the world (Collier and Hoeffler, 2004).

The rising trend of intra/ interstate (s) conflicts in Africa are partly explained by internal political, economic and ideological contradictions. Hence, eight out of the fifteen complex emergencies declared by the United Nations Department of Humanitarian Affairs in late $20^{\text {th }}$ and $21^{\text {st }}$ centuries was in Africa (Umozurike, 2005). Meanwhile, the United Nations (UN) sometimes ignored its responsibilities to keep the peace in Africa, and the African Union or its predecessor Organization of African Unity (OAU) lacks the capacity and the resources for successful peacekeeping interventions.

The tasks of managing or resolving conflicts in Africa have been profoundly difficult. Some of the theoretical bases of conflict resolution are justice, peace, security and stability of the political system (Akpuru-Aja, 2011). African Union (AU) have tried with varying degree of success (sometimes significant and most time non significant) in resolution of conflicts in Africa. In line with the Charter 33 of the United Nations, AU seeks resolution through negotiation, mediation and intermediation without an imposition of authoritative decisions. Although classical international law permitted AU to intervene under consensual arrangement by a suzerain in a protected state and on humanitarian grounds unlike the 
OAU, security challenges in African region continue to rise. International Colloquium Report (2012:15) observed that:

Despite the optimism at the launch of the AU, the African continent has subsequently continued to experience security and governance challenges. An "Afro-Arab spring" swept across North Africa beginning in January 2011, toppling long-ruling autocratic regimes in Tunisia, Egypt, and Libya. The emerging state of South Sudan, which was created in July 2011 after five decades of bitter civil war, remains fragile. Military coups took place in Madagascar in 2009, and in Mali and Guinea-Bissau in 2012, and conflicts have continued in parts of the Democratic Republic of the Congo (DRC), Somalia, and Sudan, as well as in the Central African Republic (CAR). Peace building also remains incomplete in Liberia, Sierra Leone, Côte d'Ivoire, Guinea, Algeria, Angola, Rwanda, and Burundi, while a self-determination referendum is yet to take place in Western Sahara.

This paper examines the roles, limitations and prospects of $A U$ in conflict resolution in Africa. This research was conducted using documentary analysis as well as discourse analysis approaches. Relevant portions of documents of AU and protocols in relation to conflict resolution were analyzed

\section{Conflict Management, Settlement and Resolution on a Continuum}

Conflict management tends to focus more on mitigating or controlling the destructive consequences that emanates from a given conflict than on finding solution to the underlying issues causing the conflict. It typically involves the use of military force for deterrence or peacekeeping. Conflict settlement emphasizes reaching agreement between parties through negotiation and bargaining. Conflict resolution is a more comprehensive approach based on mutual problem sharing between the conflicting parties. Deep rooted causes of conflict are addressed so that the situation is no longer violent, hostile and exploitative (Sandole \& van de Merwe, 1993). Conflict resolution elicits win-win solution and does not use coercion (Cornelius \& Faire, 1989). Although scholars have differentiated conflict management, settlement and resolution, this paper uses the concepts interchangeably, so long as the objective is to end conflict. Conflict resolution here covers the whole gamut of positive conflict handling.

\section{Rational, Architecture and Principles of AU}

The history of the African Union (AU) is connected to the formation of Organization of African Unity (OAU) on 25 May 1963. The preamble of the OAU Charter outlined the commitment of member states to collectively establish, maintain and sustain peace and security in Africa, and at the same time defend the norm of non-intervention. OAU's power to intervene in conflict situation in Africa was constrained by high respect for sovereignty, territorial integrity and independence of the member states (Murithi, 2008). Hence, OAU could not intervene in conflict situations in Angola, the Democratic Republic of the Congo (DRC), Liberia, Sierra Leone and Somalia in the 1990s.

The AU was officially launched at the 2002 Durban Summit. Article 3 ( $f \& g)$ of the Constitutive Act states that the AU shall promote peace, security and stability on the continent..., democratic principles and institutions, popular participation and good governance. It explicitly recognizes the right to intervene in a member state on a humanitarian and human rights ground (Hanson, 2009). The AU Charter specifically committed the AU to intervene in civil wars within member states and when there are clear indications of human right abuses. This is a great change from the OAU Charter that clearly prohibited the OAU (or any member states) from intervening or interfering in the internal political affairs of any member country. The AU's right of intervention derives from the ideal of Pan-Africanism and the principle of nonindifference. Those principles stipulate that African countries can no longer remain indifferent to the conflict and suffering that occurs in their neighbourhoods, and that African countries have the primary responsibility for establishing and maintaining the peace and security architecture on the continent (Murithi, 2009). This protective responsibility is implemented and coordinated by the AU's security organ, called the Peace and Security Council (PSC). The Peace and Security Council (PSC) of the African Union entered into force on 26 December 2003, putting in place a new standing body to replace the OAU Conflict Prevention, Management and Resolution Mechanism. As outlined in Article 3 of the Protocol, the objectives of the PSC are to:

- Promote peace, security and stability in Africa, in order to guarantee the protection and preservation of life and property, the well-being of the African people and their environment, as well as the creation of conditions conducive to sustainable development;

- Anticipate and prevent conflicts. In circumstances where conflicts have occurred, the Peace and Security Council shall have the responsibility to undertake peacemaking and peace building functions for the resolution of these conflicts; 
- Promote and implement peace-building and post-conflict reconstruction activities to consolidate peace and prevent the resurgence of violence;

- Coordinate and harmonize continental efforts in the prevention and combating of international terrorism in all its aspects;

- Develop a common defense policy for the Union, in accordance with Article 4(d) of the Constitutive Act;

- Promote and encourage democratic practices, good governance and the rule of law, protect human rights and fundamental freedoms, respect for the sanctity of human life and international humanitarian law, as part of efforts for preventing conflicts.

The 15-member PSC is the AU's pivotal decision-making body on conflict and crisis. The continental body's peace and security architecture includes a Panel of the Wise, which promotes high-level mediation efforts; a rapid-reaction African Standby Force (ASF) built around five sub-regional brigades; a Continental Early Warning System (CEWS); a Military Staff Committee (MSC); and a Peace Fund. The AU has adopted a holistic approach to peace building that seeks to link peace, security, and development, and emphasizes the importance of national ownership of post-conflict reconstruction efforts (International Colloquium Report, 2012). They are serviced and supported by the AU's Peace and Security Directorate (PSD), tasked with putting in place the architecture to ensure more effective African management of crises.

There are certain minimum principles that guide these institutions and sub institutions of $A U$ in conflict resolution. Article 4 of the Constitutive Act of AU outlined the basic principles of operation for the organization. Some of these principles include: sovereign equality and interdependence among Member States of the Union; respect of borders existing on achievement of independence; establishment of a common defense policy for the African Continent; peaceful resolution of conflicts among Member States of the Union through such appropriate means as may be decided upon by the Assembly; prohibition of the use of force or threat to use force among Member States of the Union; non-interference by any Member State in the internal affairs of another; the right of the Union to intervene in a Member State pursuant to a decision of the Assembly in respect of grave circumstances, namely: war crimes, genocide and crimes against humanity; the right of Member States to request intervention from the Union in order to restore peace and security; respect for democratic principles, human rights, the rule of law and good governance; promotion of social justice to ensure balanced economic development; respect for the sanctity of human life, condemnation and rejection of impunity and political assassination, acts of terrorism and subversive activities and condemnation and rejection of unconstitutional changes of governments.

\section{Root of Conflicts in Africa}

The mono cultural political economy of Africa is the immediate cause of conflict in the region. The mono- cultural capitalist economic systems in Africa make political channels necessary to obtain economic advantage. Profit maximization, privatization of means of production and extreme commoditization of labour became the character of African states after decolonization (Ake, 1981). Successive political leaderships in Africa resorted to rapacious material accumulation and failed to respond to the needs of the people. Most leaders in the region use political status to accumulate wealth by consolidating their position through electoral malpractice and suppression of citizens. Seat tight syndrome among African leaders becomes widespread. For instance, Omar Bongo of Gabon died after 42 years in power; Muammar Gaddafi of Libya has stayed 39 years in the Saddle; Teodoro Obiang Mbasong of Equatorial Guinea has held on for 30 years; Hot on his heels is Mugabe at 29 in Zimbabwe, Hosim Mubarak of Egypt stayed over 27 years in power; Paul Biya of Cameroon has been hanging on for 26 years; Yoweri Musevini of Uganda for 23 years; king Mswati 111 of Burkina Faso for 21 years and host of other. President Olusegun Obasanjo's third term bid in Nigeria was also in this direction. The saddest side of the story is that these rulers have shown lack of ability to blend strength and experience to achieve the much desired development in Africa, yet they remains in political office for self aggrandizement. Horrendous poverty, deprivation, marginalization and political corruption are prevalent in various parts of the continent despite the apparent efforts by African leaders and their external supporters to democratize and develop the region. No wonder, most conflict situations in sub-Saharan Africa are related to the struggle for national question which is usually in protection of natural resources ranging from Gold to Diamond and Tin to Crude oil. International Colloquium Report (2012:32) remarked that:

Between 1960 and 1990, no single ruling party in Africa lost power. After 2002, ruling parties were voted out of power in Benin, the Central African Republic, Ghana, Kenya, Lesotho, Mali, Mauritius, São Tomé and Príncipe, Senegal, Sierra Leone, and Zambia. In 2000, the OAU sought to end unconstitutional changes of government. The number of multi-party systems in African countries increased from five in 1989 to 35 in 1998, while the number of one-party states 
decreased from 29 to two. However, the quality of democracy arguably declined between 2005 and 2012, with political rights and civil liberties improving in 15 countries but deteriorating in 18 other states...some African leaders have deployed violence and curtailed rights during election periods in a bid to hold on to power. In 2011, state security forces in the DRC and Uganda used excessive force against opposition party supporters... At least 42 people were killed in the DRC in the days before and soon after national polls in 2011... Substantial electoral violence accompanied national polls in Kenya in 2007-2008, Zimbabwe in 2008, and Côte d'Ivoire in 2010-2011. Between 19 and 25 percent of elections in Africa are marred by conflicts... Conflicts at the polls often relate to issues such as land rights, employment, and marginalisation.

Meanwhile, the remote cause of conflicts in Africa is the arbitrariness of the boundaries of African countries initially drawn up by the European colonial powers and the breakup of European colonial empires into multiethnic states has kindled substantial intrastate violence (Ake, 1981; Aderanti, 2005). Indeed, the persistent border disputes deriving from arbitrary borders have been a common event in the sub-region. Even when the OAU enjoined governments to respect these borders in order to avoid potentially protracted, widespread conflicts that such disputes may generate, yet border disputes abound between Senegal and Mauritania, between Ghana and Togo.

This arbitrary creation of boundaries by Europeans worsened the long standing enmity among African territories. Hence, inter ethnic conflict in the African continent. Interethnic conflict are more common in Africa than anywhere else in the world (Collier, 2003). Collier and Hoeffler (2004) estimated that the rate of Africa's ethnic fractionalization at sixty-one, whereas the worldwide average outside Africa is only thirty-four. Similarly, Halebsky (1976) remarked that racial, ethnic, linguistic, and other cultural differences are main sources of conflict. Meanwhile, these differences do not breed violence but when they become politicized, they lead to conflict. Politicized conflicts are used as instruments of competition for power and resources among people from different ethnic groups.

Meanwhile, conflicts in Africa are hardly caused by a single factor rather multiplicity of factors may account for a given conflict. Ikejiaku \& Dauda (2011) show that the recent Zimbabwe and Kenyan conflicts are caused by ethnicity, rigging of elections in Africa, colonial manipulation of Africa's boundary, and longstanding land struggles. They employed the comparative perspective and contend that the primary cause of the Zimbabwe and Kenya conflicts is the failure of the governments of Mugabe and Kibaki to address the basic needs of the people. Irrespective of the cause of conflict, such tensions are accompanied by refugee flows across Africa

There is a high positive relationship between conflicts and refugee crises in sub-Saharan Africa. Salehyan and Gleditsch (2006) use a linear regression model argued that the DRC heightened its own prospects for civil war from 12 to 20 percent by accepting 670,000 refugees from Rwanda, Burundi, and the Sudan. The mass influx of Hutu refugees after the 1994 Rwandan Genocide outraged Tutsis in eastern DRC, who believed that the Mobutu government was supporting the Hutu refugees in order to destabilize the region. When Joseph Kabila overthrew Mobutu Sese Seko with the help of the Rwandan government, the Rwandan Hutus took up arms against the new government. Kabila eventually turned against his allies in Rwanda, triggering a regional war in central Africa including Rwanda, Uganda, and the DRC. Similarly, refugees from Liberia facilitated the conflicts in Sierra Leone, Cote d'Ivoire and Guinea during the late $20^{\text {th }}$ and $21^{\text {st }}$ centuries.

The policy direction of refugee host states and the activities of their security forces either heighten or reduce the probability of conflict. When the security agencies view refugee populations as administrative burdens or security threats, they consequently adopt harsh policies which may drive refugees to join armed groups. Kenya demonstrates how a host government's negative policies can contribute to political violence among its refugees. The Kenyan government treated the refugees as the UNHCR's problem and failed to provide land for the exiled populations or agree to any long-term settlement. These policies create a hostile environment and catalyzed the formation of very powerful rebel groups within the refugee camps who destabilize not only the areas around the camps, but also the entire border areas in both Sudan and Somalia. Contrarily, favourable Zimbabwean policies towards the influx of Mozambican refugees in the 1980s and Malawi's response to an exodus of over two million refugees from Mozambique during Mozambique's decades-long civil war show that favourable refugee policies can help to control the spillover of conflict to refugees host nations in Africa.

More so, AU has a number of institutions or committees through which the organization performs its political and economic coordination roles for the fifty three members in Africa. Some of these institutions were inherited from OAU while the rest were copied from European Union. These institutions include the assembly, the executive council, the permanent representative committee, the commission, the specialized technical committee, specialized technical committee, the pan-African parliament, the court of justice, the economic, social and cultural council , the financial institutions and the peace and security council. Africa Briefing Report (2011) noted that AU's strategic decision-making and policy implementation are generally affected by many factors including: weak institutional and political integration of the Regional Economic Communities (RECs). Hence, the first black President of United States, Barrack Obama correctly 
noted during his first official visit to Ghana that Africa needs strong institutions and not strong men to survive and develop in the 21stcentury.

AU's institutional weakness often degenerates to institutional failure and this is a major contributor to rising incident of conflicts across Africa. These institutions lack the cultural root and rationale to regulate behavior and conduct in citizens and states in the region. Of course these institutions are not legitimately the outcome of African cultural realities and were not structured by African cultural values but are rather they are products of global capitalist values and principles. As Africans try to adjust to these evils of capitalism, insecurity increased in the region. The problem of insecurity in Africa manifest in the forms of refugee problems; post election conflicts in Cote d' Ivoire (Nigeria, Kenya etc); border disputes (Nigeria vs Cameroon); competition for resource control (Niger Delta militancy); ethnic and religious/sectarian intolerance (Boko Haram insurgence in Nigeria, El - Shabbab in Somalia); the Arab spring (Egypt, Libya, Tunisia) indigene-settler divide, partisanship of security agencies in politics and terrorism across Africa.

\section{AU's Missions and Limitations in Africa}

In 1990, there were about 20 wars going on simultaneously in Africa but by 2010, there were only four ongoing wars and this is a big success story for AU (Ndiho, 2010). AU's first mission was deployed in Burundi where transition to self-rule was characterized by ethnic violence between the Hutu majority and the Tutsi minority. The failure of Arusha Peace and Reconciliation Agreement for Burundi signed in 2000 to consolidate the peace process in the country and the ceasefire agreement signed in 2002 without success led to the launching of the Peace Operation in Burundi (AMIB) by the AU (Rodt, 2011). In April 2003, the AU dispatched a peacekeeping mission with the task to protect, disarm, demobilize and reintegrate combatants.

The mission was described as one of the AU's biggest success stories. It made concerted efforts to prevent genocides in the Great Lakes region, and played a crucial role in the ceasefire negotiations. AU troops protected returning politicians who took part in the transnational government and provided favourable conditions for the United Nations (UN) troops, which joined in 2004 (Murithi, 2008). At the end of the AMIB mission, peace was restored to the majority of the Burundi regions, except the region outside Bujumbura, where armed national liberation forces remained a problem.

According to Africa Briefing Report (2011), there remains a discrepancy between the AfricanUnion's (AU) capacity on paper and its actual impact in crisis situations. The obstacles of the AMIB mission include inadequate equipment, food and medicine. Although the European Union (EU), the World Health Organization, the United Nations Children's Fund and the German Technical Operation were the major sources of fund, the funds arrived late when too many have died. More so, delay in deployment of troops from Ethiopia and Mozambique for Burundi was a major hindrance for the mission. The delay was due to the AU's decision that the deploying states had to finance their own troops (Rodt, 2011). Again, the Security arm of the AU, PSC also has a severe leadership and management problem and this suffocated the swift resolution of the Burundi conflicts. There is poor leadership, a lack of consensus in the AU and weak early warning capabilities in the intelligence field.

The conflict in the Democratic Republic of Congo (DRC) in 1998, between the government of Congo and armed rebel groups, sucked in neighbouring countries of Rwanda, Uganda, Angola, Zimbabwe and Namibia. There were outcries of invasion of the DRC by the neighbouring countries and rebellion by the Congolese rebel groups. Ultimately, all the parties sat together in a regional effort and considered all internal and external dimensions to the conflict. The resultant Lusaka Peace Agreement addressed the concerns of the rebel armed groups and those of the neighbouring countries. Consequently, forces of neighbouring countries withdrew and eventually, elections were held in the DRC whereas Rwanda, in particular, was concerned about the DRC's continued harbouring and supporting, on its territory, ExFAR/Interahamwe who committed genocide in Rwanda in 1994. It was only in February/March 2009 that DRC and Rwanda agreed and undertook joint operations against the Ex-FAR/Interahamwe. The same applies to the DRC and Uganda, with the participation of Sudan, in the joint operations against the Lord's Resistance Army (LRA) in the DRC. The joint operations signified a new spirit of regional commitment. The Tripartite plus Joint Commission involving Rwanda, Burundi, Uganda and DRC mediated by AU played a key role in building confidence and trust among these countries and paved the way for these bold measures (Kutesa, 2009).

Meanwhile, in Darfur, where the Arab 'white' Sudanese government fought a civil war against the predominantly black population, the AU was successful at the beginning. AU's mediation team and the Abuja Inter-Sudanese Peace Talks negotiated the signature of the N'djamena Humanitarian Ceasefire Agreement on 8 April 2004 and the Darfur Peace Agreement between the government of Sudan and the Sudanese People's Liberation Army.

Although AU received bulk of the funding from Canada, the EU, Germany, Great Britain and the United States of 
America (USA), the mission was still underfunded. Peace and Security Directorate (2008) noted that of the US\$570 million proposed by the Commission for its 2005 budget, member states only approved US $\$ 158.4$ million, little more than a quarter of what was requested. Of this amount, US\$63 million came from assessed member states contributions, which support the AU's operational and running costs. For the remaining nearly US\$100 million, the AU Commission relied on voluntary contributions from member states (the key donors being Algeria, Egypt, Libya, Nigeria and south Africa, each of whom contribute 15 percent of the budget), and grants from external donors. International Colloquium report (2012) remarked that today, over 90 percent of the AU's peace and security efforts are funded by external actors. However, the AU's lack of influence over external interventions led by the UN Security Council and its five permanent members (P-5) the United States (US), China, Russia, France, and Britain - who often have their own more parochial interests, has sometimes resulted in undesirable outcomes. Again, AU's mission in Darfur was unclear due to the different views of the members of the AU about the mission's purpose (Nikitin, 2010). Hence, AU admitted its limitation and joined with the UN in a UN-AU Hybrid Mission in Darfur (UNAMID).

The civil war in the ethnically homogenous country of Somalia, led the PSC to establish the African Union Mission in Somalia (AMISOM) with the purpose to stabilize the situation in the country and to promote dialogue, facilitate the provision of humanitarian assistance and create conditions for a long-term peace. The mission did not undertake any urgently needed confidence-building measures and in 2007, AU revealed the weakness of its peacekeeping mission to Somalia and inadequacy of the mission regarding the complexity of the situation (Marangio, 2012; Pavšič, 2013).

Other major roles of AU include AU brokering of a power-sharing agreement and deployment of a 462-strong force to support elections in the Comoros in May 2006, providing an important security presence that eased the passage of democracy. African troops supported the Comorian armed forces to remove self-styled 'President' Mohammed Bacar from power in Anjouan in March 2008. The African Union did so at the request of Abdallah Sambi, the President of the Union of Comoros (Kutesa, 2009) . In the same vein, African Heads of State suspended Member State of the African Union that removed democratically elected government by unconstitutional means. It is in implementation of this that Mauritania, Guinea Conakry and Madagascar were suspended from the AU until the constitutional order was restored in those countries. AU also prevented the crisis in Niger by suspending the country's membership in February 2010 after the military coup, and demanded a return to constitutional order. Although the African Charter on Democracy, Elections and Governance (ACDEG), adopted in 2007 exists, the Member States hardly adhere to nor commit themselves to its norms and values. The same observation goes for the Panel of the Wise (not being fully involved in its conflict resolution efforts) and the African Standby Force (ASF) (its establishment being delayed) (Africa Briefing Report, 2011).

AU's lack of good communication tools; management capacity and positive visibility especially in the recent crises in Libya and Côte d'Ivoire have soiled the credibility, authority and reliability of the organization. According to Africa Briefing Report (2011), the proposed AU roadmap for resolving the conflict in the Libya crisis has not been given proper attention by the international community, and has rather been criticized within and outside the continent. The AU appears to have lost credibility due to the interplay of the following fundamental factors: perception- the popular protests in Libyan and the Middle East have been perceived as an 'Arab Spring', rather than an African issue; internal divisions- South Africa, Gabon and Nigeria voted in favour of UNSCR 1973, despite the AU High Panel (Toumani Ture/Mali, Zuma/RSA Museveni/Uganda, Abdul Aziz/Mauritanie, Nguesso/C-Brazzaville) taking a different position; subsequently, the AU fivepoint roadmap, which included a ceasefire, the protection of civilians, humanitarian aid, dialogue, and an inclusive transitional period, meeting the aspirations of the Libyan people gathered much criticism. The AU's mediation proposals were rejected by the Libyan opposition (Transnational National Council), which insisted on Gaddafi's departure.

Similarly, the AU has also been criticized for having mismanaged the quick resolution of the conflict in Côte d'Ivoire, among others, by not being forthright in supporting the ECOWAS position on intervention. The situation in Côte d'Ivoire showed that the AU Panel lacked a coherent strategy. The AU's choice to send Thabo Mbeki to resolve the dispute between Gbagbo and Ouattara in December 2010 failed on two accounts. First, Mbeki did not combine efforts with ECOWAS. Second, South Africa was seen as a peacemaker that often opted for a pro-government (in this case proGbagbo) approach. Similarly, Ralia Odinga compromised his neutrality as a mediator when he supported military action prior to confirmation by ECOWAS. President Bingu wa Mutharika visit to Côte d'Ivoire in an effort to salvage the declining role of the AU, proved unsuccessful and Teodora Nguema was considered too controversial to be involved in the resolution of the crisis because of his questionable human rights credentials. The AU attempts at a peaceful resolution of the Côte d'Ivoire crisis was hampered many times by internal divisions between Member States that undermined the credibility of the $\mathrm{AU}$ as the main political mediator. These divisions were reflected within the AU mediation team (Africa Briefing Report, 2011). 


\section{In Lieu of Conclusion: AU's Prospects for Conflict Resolution}

Regional efforts at conflict resolution in Africa have been successful where they have occurred except where the aggrieved parties fail to implement agreed positions because of various reasons, including external interference, and internal constraints. AU has played very important role in conflict resolution through mediations and peacekeeping operations in the region. At least AU raises the alarm for international community to intervene. AU also has a significant contribution of African troops and police. African engagement has also served as a catalyst for international support and the return of UN peacekeepers to Africa (MONUC in Congo, UNMIS in Southern Sudan and UNAMID in Darfur) after the tragedies of Somalia and Rwanda in the early 1990s.

However, AU's missions have similar limitations. AU faces financial barriers engendered by extreme poverty among its member as well as dearth of technical capacity. In 2006 only 12 countries paid their yearly contributions. In fact, some countries are too poor and too internally devastated by their own conflicts, and cannot afford to participate in other conflicts. Indeed, African political economy is largely characterized by socio-economic and political instability; conflicting religious, regional and ethnic interests; unbridle corruption. AU heavily relies on the political and economic support from the regional institutions and the international community who also has limited resources and is often too slow in decision-making and rigid in their decisions about funding. This is largely because AU's peace and security machinery cannot focus effectively on more than one trouble spot at a time. For instance, with conflicts in Cote D'Ivoire, the Democratic Republic of Congo, Chad and most recently Somalia began to take a relative back seat. Hence, almost all AU missions were later taken over by the UN and none of the AU missions identified here succeeded without the UN's assistance.

The AU should insist on improvement of the governance institutions in order respond to the basic needs of the populations. Absence of such governance institution in Kenya and Zimbabwe heightened the conflicts in the countries. Again, membership of $\mathrm{AU}$ should be based on certain minimum requirements including respect for rule of law, free and fair election, stable democratic government, security sector reforms, obvious efforts to combat corruption and readiness to cooperate with other states in the region in specific areas. States that do not meet these requirements should not be AU members. The suspension of the states of Mauritania, Guinea Conakry and Madagascar for undemocratically ousting their democratically elected leaders is commendable. African states should also depoliticize their ethnic/ religious differences and promote national mechanisms for conflict resolution for early response to conflicts. AU should also appropriate over $70 \%$ of her annual budget to a special fund for responding to conflict emergencies (dominant emergency in Africa) so that it will respond swiftly to conflict emergencies.

\section{Acknowledgement}

We acknowledge Dr. Nonso Oguonu and Pham Mrs. Ezinwanne Ezeibe. They helped in the sourcing of the documents used for this article.

\section{References}

Aderanti A. (2005) "Migration in West Africa", A paper prepared for the Policy Analysis and Research Programme of the Global Commission on International Migration, September.

Africa Briefing Report (2011) "The African Union's role in the Libya and Côte d'Ivoire conflicts", Brussels - 16 May

Aja-Apkuru, A. (2011) Homeland Security System and Conflict Management in Crisis Ridden Boundaries in Nigeria", in O. Mbachu \& A. Sokoto (eds) Nigeria Defense and Security : Policies and Strategies. Kaduna: Medusa Academic Publishers Limited 255-268

Ake C (1981) A Political Economy of Africa. Lagos: Longman Group Ltd.

Akuffo, E.A. (2010) "Cooperating for peace and security or competing for legitimacy in Africa? The case of the African Union in Darfur", African Security Review, 19(4): 74-89.

Collier, P. and Hoeffler, A. (2004) "Greed and Grievance in Civil War", Oxford Economic Papers, (56): 563-595

Collier, P. et al. (2003) Breaking the Conflict Trap: Civil War and Development Policy. Washington, D.C., \& New York: World Bank and Oxford University Press.

Cornelius, H. \& Faire, S. (1989) Everyone can win: How to Resolve Conflict. Australia: Simon \& Schuster

Halebsky, S. (1976): Mass Society and Political Conflict: Towards a Reconstruction of Theory. London: Cambridge University Press.

Hanson, S. (2009) 'The African Union', Council on Foreign Relations. Retrieved from http://www.cfr.org.

Ikejiaku, B. \& Dauda, J. (2011) "African Union, conflict, and conflict resolution in Africa: a comparative analysis of the recent Kenya and Zimbabwe conflicts", Int. j. of dev. and conflict 01(1)

International Colloquium Report (2012) "The African Union at Ten: Problems, Progress, and Prospects". Berlin, Germany, 30-31 August Jeng, A. (2010) "Enforcing the African Union peace and security framework in Burundi", Journal of Law and Conflict Resolution, 2(8): 
116-128.

Kutesa, S.K. (2009) "Peace and Conflict Resolution in Africa". Paper presented by the Ugandan Foreign Affairs Minister in JICA, Tokyo, Japan, June.

Marangio, R. (2012) "The Somali crisis: Failed state and international intervention", Istituto Affari Internazionali Working Papers 12-15, May

Murithi, T. (2008) "The African Union's evolving role in peace operations: The African Union Mission in Burundi, the African Union Mission in Sudan and the African Union Mission in Somalia", African Security Review, 17(1): 69-82.

Murithi, T. (2009) 'The African Union's transition from non-intervention to non-indifference: An ad hoc approach to the Responsibility to Protect?'. Retrieved from http://library.fes.de.

Ncube, J. and Akena, A.M. (2012) "A stream cannot rise above its source", Pambazuka News, 22 November.

Ndiho, P. (2010): "African Union Plays a Significant Role in Conflict Resolution. Retrieved from http://www.vipiafrica.com/ 2010/11/african-I. 22/08/12.

Nikitin, B.S. (2010) "Report: The Positive Impact of African Union Forces on Darfur", Student Pulse, 2(1): 1-3.

Pavšič , P (2013) "The African Union: A noble idea or an effective provider of peace and security on the African continent?", Consultancy Africa Intelligence, 16 January

Peace and Security Directorate (2008) "African Union Peace \& Security Framework and Mechanisms", Addis Ababa: Peace and Security Directorate

Rodt, A.P. (2011) "The African Mission in Burundi: The successful management of violent ethno-political conflict?", Ethnopolitics Papers, 10: 1-27;

Salehyan, I. and Gleditsch, K. (2006) "Refugees and the Spread of Civil War", International Organization, 60 ( 2): 335-366

Sandole, D.J.D. \& van de Merwe, H. (1993) Conflict Resolution Theory and Practice: Integration and Application. Manchester: Manchester University Press.

The OAU: Declaration on a Mechanism for Conflict Prevention, Management and Resolution. Retrieved from http://www.dipublico.com. ar/english/treaties/oau-declaration-on-amechanism 22/10/12

Umozurike, U.O. (2005) Introduction to International Law (5 $5^{\text {th }}$ Edition). Ibadan: Spectrum Books Ltd. 